\title{
Minimum Standards, Fixed Costs and Taxing Autonomy of Subnational Governments
}

\author{
HELMUT SEITZ
}

CESIFO WORKING PAPER NO. 2341

CATEGORY 1: PubliC FinANCE

JUNE 2008

\footnotetext{
An electronic version of the paper may be downloaded

- from the SSRN website: www.SSRN.com

- from the RePEc website: - from the CESifo website: 


\title{
Minimum Standards, Fixed Costs and Taxing Autonomy of Subnational Governments
}

\begin{abstract}
The paper examines the question how fiscally strong and fiscally weak states respond to taxing autonomy at the state level, a subject that is currently under debate in Germany where states do have virtually no power to tax. We use a simple theoretical model that incorporates state surtaxes on the federal income tax bill taking into account fixed costs as well as minimum standards for the provision of public services. We show that both factors work in the direction of forcing fiscally weak states to collect higher surtaxes as compared to fiscally strong states. The empirical section presents evidence on the importance of fixed costs at the state level and calculates the distributional effects of taxing autonomy taking feedbacks of the fiscal equalization system into account. In addition simple estimates of the importance of spending on minimum standards are derived.
\end{abstract}

JEL Code: H11, H50, H71.

Keywords: fiscal federalism, minimum standards, tax autonomy, fiscal equalization.

\author{
Helmut Seitz \\ Technical University Dresden \\ Department of Business Management and Economics \\ 01062 Dresden \\ Germany \\ helmut.seitz@tu-dresden.de
}

June 2008

The author gratefully acknowledges support by the German Research Foundation (DFG), project number SE 540/2-1. The paper has been prepared within the research project (DFGSchwerpunktprogramm) "Governance of federal systems: theoretical approaches and empirical evidence ("Institutionelle Gestaltung föderaler Systeme: Theorie und Empirie"). The paper benefited from discussions and suggestions for improvement by Clements Fuest, Wolfgang Peters, Marcel Thum and Matthias Wrede. 


\section{Introduction}

In Germany state governments virtually do not have any power to tax. Most of tax revenues come out of shared tax resources with tax rates fixed by the federal government and with one exception only even tax rates of taxes that are earmarked to the state level are regulated by federal law. This lack of taxing autonomy is a constant source of dispute in politics as well as in the academic discussion in Germany, see Baretti et al. (2000) for a detailed presentation. In 2002 Germany started a broad discussion on reforming the fiscal federalism system. However, the first reform period was stopped by the federal election campaign in 2005 and produced only modest reforms. After the 2005 federal elections a second reform process was initiated in which the subject of federal-state fiscal relations is on the top of the policy agenda. The topics of most importance in the current reform process are deficit control mechanisms at the state and federal government level, a reform of the division of tasks between the central and the subnational government sector and the issue of granting more taxing autonomy to the states. ${ }^{1}$ Thus a piggybacking system is proposed in which states should have the right to collect a surtax on federal income taxes and to restrict this surtax to some band limits, such as $+/$ $10 \%$ of federal income tax payments. ${ }^{2}$ The latter issue is the subject of the present paper.

The taxing autonomy issue at the state level is dominated by two quite extreme positions. On the one hand, politicians especially from fiscally strong states, argue that introducing taxing autonomy at the state level helps to improve fiscal discipline, strengthens the accountability and transparency of responsibilities and supports the international competitiveness of the German economy. On the other hand, policy makers from fiscally weaker states as well as academics that fear a race to the bottom ${ }^{3}$ of surtaxes in the tax competition process are against state taxing autonomy. Public opinion also matters. A recent survey by the Bertelsmann Stiftung, see Bertelsmann Stiftung (2008), which is a private nonparty operating foundation, examined the opinion of citizens in Germany on federal institutions and reforms in federalism in Germany. According to the survey results more than $80 \%$ of respondents indicated that they did not want differences in tax rates across the German states. This result was independent of political preferences of citizens as well as whether citizens live in fiscally strong or fiscally weak states. The survey results also suggested that citizens are quite critical with respect to granting more autonomy to states, ranging from tax policy and environmental policy to state autonomy in educational matters. ${ }^{4}$

\footnotetext{
${ }^{1}$ See Jourmard and Kongsrud (2003) for a general discussion of subnational government taxing autonomy as well as information on the handling of this issue in various countries.

${ }^{2}$ As is common in the Nordic countries.

${ }^{3}$ See for example OECD (1998).

${ }^{4}$ However, the survey results indicated that citizens want to have more autonomy for local governments. Thus citizens make a clear distinction between the local, state and federal government level.
} 
The present paper addresses the issue of the effects of taxing autonomy on fiscally strong and fiscally weak states, an issue that is not that systematically addressed in the literature, see however Fuest (2008) for a recent contribution. The tax competition literature addressing asymmetries between jurisdictions almost exclusively in terms of size differences, see for example Hoyt (1992). Before we turn to our theoretical model section 2 provides a short description of some important peculiarities of fiscal federalism in Germany that are worth knowing in order to understand our modeling strategy as well as our empirical analysis. Section 3 presents a simple theoretical model that incorporates features that are of crucial importance in the German discussion on taxing autonomy. Our model takes into account the fiscal equalization system that brings about an equalization of revenues across states with above and below average fiscal capacity. In addition, we incorporate minimum standards for the provision of public services which will turn out to be of quite significant importance. Finally, we model fixed cost at the state level. These fixed costs are not interpreted as fixed costs of running a state - such as the administrative infrastructure - but in terms of the fiscal burden due to political decisions made in the past. In Germany, in fiscally weak states per capita interest payments as well as per capita spending for retired public servants is higher as compared to fiscally strong states. Thus fiscally weak states fear that they would be forced to enter an "unfair" competition if taxing autonomy is introduced because they have a below average tax base, a far above average inherited fiscal burden and are forced to provide a high standard of minimum public services provision. Therefore it is feared that taxing autonomy might contribute to an increase in fiscal disparities across states. ${ }^{5}$ We use our model to evaluate these arguments and also present some simulation experiments which show, that the seriousness of these arguments critically depend upon the importance of minimum standards. Section 4 reports empirical evidence on the main ingredients of our theoretical model. We examine the distributional impact of introducing taxing autonomy at the state level taking the fiscal equalization system into account. In addition, we report evidence on the importance of fixed cost and minimum standard spending at the state level. However, both our theoretical work in section 3 as well as our empirical investigation in section 4 disregards the potential feedback effects that might result from the long-run effects induced by state tax competition on the distribution of the population and income across states. Thus, we either implicitly assume that the impact of income tax competition on interregional migration flows of households is rather small or our theoretical model and our empirical results hold for the short-run or medium run only.

Whereas the issues discussed in this paper are of not that much importance for federal systems with a well developed taxing autonomy of subnational government, such as the U.S., Switzerland or Canada, the subject should be of interest in federal countries with a taxation system similar to Germany and especially economies in Eastern Europe or in developing countries that are in the process of creating federalist structures.

\footnotetext{
${ }^{5}$ Prud'homme (1995) provides an extensive discussion on the impact of subnational government autonomy on fiscal and economic disparities.
} 


\section{Fiscal Federalism in Germany in a nutshell}

In Germany there are 16 states (Länder), three of which are in fact large cities (Berlin, Hamburg and Bremen) and are called "city states". The other thirteen states are called "area states" and each area state consists of numerous cities, towns and villages. Five of the area states have been formed in 1990 out of the collapsed GDR (East German states). The city state Berlin is a mixture of the former West Berlin and East Berlin. Berlin as well as the East German states receive significant federal grants for the reconstruction of the infrastructure that will terminate in 2019.

The discussion in Germany on fiscal federalism cannot be understood without taking a look at the German Constitution. The German Constitution, the Basic Law of the Federal Republic of Germany, asks for the achievement of "equal living conditions" throughout the country in Article 72, sect. 2:

"The Federation shall have the right to legislate ... if and to the extent that the establishment of equal living conditions throughout the federal territory or the maintenance of legal or economic unity renders federal regulation necessary in the national interest."

Political discussions that have regional distributional effects are always influenced by referring to the Constitutional command to achieve "equal living conditions". Neither the Constitution nor policy makers or academics can provide a precise definition of what "equal living conditions" really means. However, the simple reference to this Constitutional restriction makes it hard for politicians to implement programs or reforms which are expected to increase regional disparities.

Tax revenues in Germany are collected from two types of taxes. The majority of taxes are 'joint taxes' i. e. the revenue out of these taxes are shared between the federal, state and the local government sector. The revenues are distributed vertically according to negotiated shares, some of which are fixed in the Constitution. About $75 \%$ of all tax revenues belong to this category. Only $25 \%$ of tax revenues are derived from taxes earmarked to one level of government only. Currently, the German states ${ }^{6}$ do have virtually no power to set tax rates despite the fact that about $73 \%$ of the states' total revenues come out of taxes. Tax rates are set by the federal government. However, if tax rates of joint taxes or tax rates of taxes that are earmarked to the states are changed, states participate in the legislation process through voting in the Upper Chamber (Bundesrat). Thus, the states can jointly influence tax policy but none of the states can fix tax rates individually.

\footnotetext{
${ }^{6}$ Contrary to the states, the local governments can decide - more or less independently - on the tax rates of local property taxes (Grundsteuer) and the local business tax (Gewerbesteuer).
} 
Table 1 reports some key data on the distribution of tax revenues in Germany across the three layers of government. About $87 \%$ of state tax revenues come out of joint taxes with tax rates fixed nationwide by the federal government. With one exception only, tax rates of taxes earmarked to the state level are also beyond the control of individual states. Since 2006 states have the right to fix the rate of the real property transfer tax (Grunderwerbssteuer) the revenues of which amounts to only about $3.5 \%$ of total state tax revenues. ${ }^{7}$ This complete lack of the power to tax of German states is frequently discussed in Germany and the central topic of this paper. ${ }^{8}$

Table 1: Distribution of tax revenues in Germany among federal, state and local governments (institutional setting and revenue data from 2006).

\begin{tabular}{|l|r|r|r|r|}
\hline & Federal & \multicolumn{1}{|c|}{ States } & \multicolumn{1}{c|}{$\begin{array}{c}\text { local } \\
\text { governments }\end{array}$} & $\begin{array}{c}\text { total revenue } \\
2006 \text { in bill. } \varepsilon^{1)}\end{array}$ \\
\hline 1. Value added tax & $\sim 53.1 \%$ & $\sim 44.8 \%$ & $\sim 2.1 \%$ & 111.3 \\
2. Income tax incl. wage tax & $42.5 \%$ & $42.5 \%$ & $15.0 \%$ & 140.2 \\
3. Non-assessed taxes on Earnings & $50.0 \%$ & $50.0 \%$ & $0.0 \%$ & 11.9 \\
4. Interest income deduction & $44.0 \%$ & $44.0 \%$ & $12.0 \%$ & 7,6 \\
5. Corporation tax & $50.0 \%$ & $50.0 \%$ & $0.0 \%$ & 22,9 \\
\hline A. joint taxes (1.-5.) in bill. $€$ & 162.8 & 148,5 & 18,0 & 329.3 \\
\hline B. Taxes earmarked to one level of & 84,2 & 21,7 & 49,3 & 155.2 \\
government in bill. $€$ & & & & 484.5 \\
\hline C. Total tax revenues in bill. $€$ & 247,0 & 170,2 & 67,3 & \\
\hline
\end{tabular}

Source: Federal Ministry of Finance, Berlin, Germany.

Apart from the high share of shared tax resources a second important characteristic of the fiscal federalism system in Germany is a rather pronounced horizontal fiscal equalization system that redistributes state tax revenues across states. As mentioned above, joint taxes are distributed vertically between the three layers of government. State tax revenue resulting out of joint taxes - with the exception of the VAT - are distributed across the individual states according to the tax revenues collected in each state. Revenues of taxes that accrue to the state level only are also assigned to the state where these tax revenues are collected. The distribution of states' revenue share of VAT is described below.

Because the fiscal equalization system is very complicated and the details are not of that much importance for our subsequent discussion, we restrict our attention to the distributional effects of this system. Table 2 reports data on tax revenues and the effects of the fiscal equalization system in the fiscal year 2007. Because tax revenues of local governments are taken into account in the fiscal equalization system, we also report tax revenues at the local government level as well as at the aggregate of the state and local government level in each states. We sorted states into three groups (eight West German area states, five East German area states and three city states) and each group has

\footnotetext{
${ }^{7}$ It is interesting to note that up to the present out of the 16 states only the state Berlin has used this power to change (increase) this tax rate.

${ }^{8}$ In passing we note that despite the lack of taxing power states are responsible for tax collection and tax administration.
} 
been sorted in order of increasing fiscal capacity at the state and local government level. Column (1) reports the population in 2007 in mill., and we see that states differ dramatically with respect to population size, ranging from about 0.7 mill. inhabitants in the city state Bremen to about 18 mill. inhabitants in Nordrhein-Westfalen. Column (2a) shows state per capita tax revenues out of earmarked and joint tax resources - excluding VAT - and in column (2b) we express these figures in \% of the national average. As we can see, the East German states have a fiscal capacity that is less than $50 \%$ of the national average. In West Germany the relation ranges from about $80 \%$ (Saarland) to about $170 \%$ (Hamburg) of average per capita state tax revenues. In column (3a) we add revenues out of the VAT which are distributed in a first step according to the number of inhabitants in each state. This brings about a significant equalizing effect, see column (3b), especially in the East German states. Because in the fiscal equalization system local government tax revenues are included, column (4a) reports per capita local government tax revenues. ${ }^{9}$ Here too, see column (4b), we observe dramatic interregional disparities in tax revenues that coincide with disparities at the state level. Column (5) reports total per capita redistribution transfers in the fiscal equalization system. Redistribution occurs in two steps, which are not documented separately. In a first step VAT revenues are redistributed in favor of fiscally weak states which has a very strong equalizing effect. In a second step a further equalization of tax revenues including VAT is calculated. A minus entry in column (5) means that the state has to make transfer payments whereas a plus entry indicates a recipient state. In the East German states transfers received amount to more than $50 \%$ of own tax revenues as reported in column (3a). Column (6a) adds total state tax revenues and transfers. As we can see a rather "perverse" effect occurs at the state level because the very poor East German states have above average revenues at the state level after euqalization, see column (6b). ${ }^{10}$ The reason ${ }^{11}$ for this is the inclusion of local government tax revenues in the fiscal equalization system. Therefore we report total aggregate revenue at the state and local government sector in column (7a). Here we observe, see column (7b), that per capita revenue in East Germany is about $10 \%$ below the average. ${ }^{12}$ In West Germany, the poorest state (Niedersachsen) has about $93 \%$ of average per capita revenue whereas Hamburg, which is the richest state, has about $141 \%$ of the average per capita revenue.

\footnotetext{
${ }^{9}$ In the fiscal equalization system only $64 \%$ of local tax revenues are taken into account. In table 2 we report total local government revenues.

${ }^{10}$ Another "perverse" effects occurs for city states. The reason for this is the fact, that in the fiscal equalization system the number of inhabitants of city states is artificially increased by $35 \%$ because it is argued that agglomerations have higher fiscal needs, an issue that is almost permanently under dispute in Germany.

${ }^{11}$ However, one has to take into account that because of the poor fiscal capacity of the local government sector in East Germany, see column (4b), East German states have to provide far above average unconditional grants to local governments, which exceed the West German average value by about $100 \%$ ! Thus "disposable tax revenue" of East German states - state tax revenues including fiscal equalization transfers net of transfers to the local government sector - are lower as compared to West German states.

${ }^{12}$ Our presentation of the fiscal equalization system does not include another equalizing step, namely additional federal transfers, that bring about a further increase of per capita revenues of fiscally weak states.
} 
Table 2: Per capita tax revenues at the state and local government level and redistribution in Germany in 2007

\begin{tabular}{|c|c|c|c|c|c|c|c|c|c|c|c|c|}
\hline & $\begin{array}{l}\text { Population } \\
\text { in Mill. }\end{array}$ & \multicolumn{2}{|c|}{$\begin{array}{l}\text { State tax revenues } \\
\text { without VAT }\end{array}$} & \multicolumn{2}{|c|}{$\begin{array}{l}\text { State tax revenues } \\
\text { including VAT }\end{array}$} & \multicolumn{2}{|c|}{$\begin{array}{l}\text { Local government tax } \\
\text { revenues }\end{array}$} & $\begin{array}{l}\text { Redistri- } \\
\text { bution }\end{array}$ & \multicolumn{2}{|c|}{$\begin{array}{l}\text { Total state tax revenue } \\
\text { after redistribution }\end{array}$} & \multicolumn{2}{|c|}{$\begin{array}{l}\text { State and local gov. tax } \\
\text { revenues after } \\
\text { redistribution }\end{array}$} \\
\hline & \multicolumn{12}{|c|}{ West German area states } \\
\hline & (1) & $(2 a)$ & $(2 \mathrm{~b})$ & $(3 a)$ & $(3 b)$ & $(4 a)$ & $(4 b)$ & $(5)$ & $(6 a)$ & $(6 b)$ & (7a) & $(7 b)$ \\
\hline Hessen & 6,1 & 2.036 & $145,1 \%$ & 2.936 & $127,5 \%$ & 1.163 & $128,3 \%$ & -644 & 2.292 & $99,5 \%$ & 3.454 & $107,6 \%$ \\
\hline $\begin{array}{l}\text { Baden- } \\
\text { Württemberg }\end{array}$ & 10,7 & 1.696 & $120,8 \%$ & 2.595 & $112,7 \%$ & 1.100 & $121,4 \%$ & -359 & 2.237 & $97,1 \%$ & 3.337 & $104,0 \%$ \\
\hline Bayern & 12,5 & 1.700 & $121,1 \%$ & 2.599 & $112,8 \%$ & 1.046 & $115,5 \%$ & -336 & 2.263 & $98,2 \%$ & 3.309 & $103,1 \%$ \\
\hline $\begin{array}{l}\text { Nordrhein- } \\
\text { Westfalen }\end{array}$ & 18,0 & 1.474 & $105,0 \%$ & 2.374 & $103,1 \%$ & 955 & $105,4 \%$ & -158 & 2.216 & $96,2 \%$ & 3.171 & $98,8 \%$ \\
\hline $\begin{array}{l}\text { Schleswig- } \\
\text { Holstein }\end{array}$ & 2,8 & 1.287 & $91,7 \%$ & 2.186 & $94,9 \%$ & 876 & $96,7 \%$ & -5 & 2.181 & $94,7 \%$ & 3.057 & $95,3 \%$ \\
\hline $\begin{array}{l}\text { Rheinland- } \\
\text { Pfalz }\end{array}$ & 4,0 & 1.294 & $92,2 \%$ & 2.194 & $95,2 \%$ & 826 & $91,1 \%$ & 28 & 2.222 & $96,5 \%$ & 3.048 & $95,0 \%$ \\
\hline Saarland & 1,0 & 1.123 & $80,0 \%$ & 2.023 & $87,8 \%$ & 760 & $83,9 \%$ & 225 & 2.248 & $97,6 \%$ & 3.008 & $93,7 \%$ \\
\hline \multirow[t]{2}{*}{ Niedersachsen } & 8,0 & 1.192 & $84,9 \%$ & 2.092 & $90,8 \%$ & 799 & $88,2 \%$ & 78 & 2.170 & $94,2 \%$ & 2.970 & $92,5 \%$ \\
\hline & \multicolumn{12}{|c|}{ East German area states } \\
\hline $\begin{array}{l}\text { Sachsen- } \\
\text { Anhalt }\end{array}$ & 2,4 & 680 & $48,4 \%$ & 1.580 & $68,6 \%$ & 527 & $58,2 \%$ & 776 & 2.356 & $102,3 \%$ & 2.883 & $89,8 \%$ \\
\hline Brandenburg & 2,5 & 719 & $51,2 \%$ & 1.618 & $70,2 \%$ & 512 & $56,5 \%$ & 749 & 2.368 & $102,8 \%$ & 2.879 & $89,7 \%$ \\
\hline $\begin{array}{l}\text { Mecklenburg- } \\
\text { Vorpommern }\end{array}$ & 1,7 & 579 & $41,2 \%$ & 1.478 & $64,2 \%$ & 455 & $50,2 \%$ & 922 & 2.400 & $104,2 \%$ & 2.855 & $89,0 \%$ \\
\hline Sachsen & 4,2 & 632 & $45,0 \%$ & 1.531 & $66,5 \%$ & 468 & $51,6 \%$ & 843 & 2.375 & $103,1 \%$ & 2.842 & $88,6 \%$ \\
\hline Thüringen & 2,3 & 593 & $42,3 \%$ & 1.493 & $64,8 \%$ & 458 & $50,6 \%$ & 885 & 2.378 & $103,3 \%$ & 2.837 & $88,4 \%$ \\
\hline & \multicolumn{12}{|c|}{ city states } \\
\hline Hamburg & 1,8 & 2.365 & $168,5 \%$ & 3.265 & $141,7 \%$ & 1.629 & $179,8 \%$ & -363 & 2.902 & $126,0 \%$ & 4.531 & $141,2 \%$ \\
\hline Bremen & 0,7 & 1.409 & $100,4 \%$ & 2.309 & $100,2 \%$ & 988 & $109,0 \%$ & 553 & 2.862 & $124,3 \%$ & 3.850 & $120,0 \%$ \\
\hline Berlin & 3,4 & 1.150 & $81,9 \%$ & 2.050 & $89,0 \%$ & 723 & $79,8 \%$ & 933 & 2.983 & $129,5 \%$ & 3.706 & $115,5 \%$ \\
\hline all states & 82,3 & $1.403,8$ & $100,0 \%$ & $2.303,4$ & $100,0 \%$ & 906,0 & $100,0 \%$ & 0,0 & $2.303,4$ & $100,0 \%$ & $3.209,5$ & $100,0 \%$ \\
\hline
\end{tabular}

Source: Calculations by the author using data supplied by the federal ministry of finance, Berlin, Germany. 
Without looking detailed at each figure in table 2 one can immediately see that the distributional impact of the fiscal equalization system in Germany is very strong, and it should be no surprise that this provokes permanent discussions in politics and academics, see Baretti, Huber and Lichtblau (2002). If there would be no fiscal equalization system and if VAT would be distributed using the state population share, the East German states would have per capita tax revenues at the aggregate state and local government level that amount to about $62 \%$ of the average value. In West Germany, average per capita tax revenues would range from about $87 \%$ (Saarland) to about $153 \%$ (Hamburg) of the average per capita tax revenue. The fiscal equalization system reduces these fiscal disparities across all states to the range of $88 \%$ to $140 \%$, see column ( $7 \mathrm{~b})$.

As a matter of course, the quite significant equalizing effects are associated with massive transfer payments of fiscally strong states and these states make massive political lobby work to reduce the transfer burden. Taxing autonomy is one option to reduce the transfer burden because, as we will argue in the next section, introducing taxing autonomy requests that all or at least a significant share of tax revenues collected from applying surtaxes have to be taken out of the fiscal equalization system. Thus the discussion in Germany on the taxing autonomy is closely related to issues of interregional fiscal disparities and distribution.

\section{A simple theoretical model}

Our model rests upon a theoretical framework suggested by Fuest (2008) which we extent by incorporating a minimum standard for the provision of public services. As we will show this assumption crucially affects the differences of tax rates between states with above and below average tax capacity.

\section{The model setup}

We assume that the $\mathrm{i}=1, \ldots \mathrm{n}$ German states are allowed to collect a surtax on the federal income tax. States differ with respect to the number of inhabitants, $m_{i}$, and average taxable income, $y_{i}$, which is taxed by a federal tax rate as well as a state surtax, $t_{i \cdot}{ }^{13}$ The strong fiscal equalization system in Germany that we outlined in the previous section can be modeled in a highly stylized per capita form as:

$$
z_{i}=b\left(\bar{r}-r_{i}\right)
$$

\footnotetext{
${ }^{13}$ We do not take into account issues of vertical tax competition which are considered for example by Keen and Kotsogiannis (2002) or Keen (1998).
} 
with $\bar{r}$ denoting average per capita tax revenues across all states and $\mathrm{r}_{\mathrm{i}}$ per capita tax revenues in state i. $z_{i}$ are per capita transfers received by states with below-average tax capacity $\left(r_{i}<\bar{r} \rightarrow z_{i}>0\right)$ or per capita transfer payments if the state has an above average tax capacity $\left(r_{i}>\bar{r} \rightarrow z_{i}<0\right)$. The parameter $b, 0<b<1$, determines the intensity of the fiscal equalization system. The larger $b$, the stronger is the equalizing effect. We assume that tax revenues in state $i$ are proportional to average income in state $\mathrm{i}, y_{i}$, and we model two types of tax revenues. The first type are income tax revenues and the second type are all other tax revenues, the tax rates of which are fixed by federal law and cannot be manipulated by states.

As set out in section 2, currently the income tax is shared between the federal, local and state government level and $42.5 \%$ of the income taxes collected within states accrue to the state level. Thus the implicit state income rate is currently given by $0.425 \tau$ where $\tau$ is the federal income tax rate which is identical across all states. Because the introduction of tax autonomy is not designed to increase the general income tax rate the federal tax rate would have to be reduced as for example by the average surtax expected to be collected by states. ${ }^{14}$ In addition, an introduction of tax autonomy in federal systems with fiscal equalization is only meaningful if tax revenues collected out of the surtax are not fully taken into account in the fiscal equalization system ${ }^{15}$ and the outcome of the fiscal equalization system is not affected by differences in state surtaxes. Thus total income tax revenues of state $\mathrm{i}$ are given by $\left(s+t_{i}\right) y_{i}$, where $s$ denotes the income tax rate due to federal tax laws after introducing taxing autonomy $(s<0.425 \tau)$ and $t_{i}$ the surtax in state i. In the fiscal equalization system only the federal income tax revenues $s y_{i}$ are taken into account and thus we can rewrite the fiscal equalization system in per capita form as:

$$
z_{i}=b\left(\bar{y}-y_{i}\right)\left(s+t^{d}\right)
$$

where $t^{d}$ denotes the tax rate (fixed by federal tax laws) on all other taxes and $\bar{y}$ is the average income across all states, which could also be set equal to zero without loss of generality. Note, that tax revenues collected from applying state surtaxes are not taken into account in the fiscal equalization system $\left(1^{\prime}\right)$. Thus there is no direct impact of state differences in surtaxes on the fiscal equalization system. However, indirect effects would arise if differences in state tax surcharges induce migration and thus affect both $y_{i}$ and $m_{i}$.

Total per capita state revenues are given by

$$
r_{i}=y_{i}\left(s+t^{d}+t_{i}\right)+z_{i} .
$$

\footnotetext{
${ }^{14}$ In addition, the revenue share of states has to be adjusted.

${ }^{15}$ Keen (1998) stresses the role of fiscal equalization systems as an instrument to internalize fiscal externalities within a federal system. This role as matter of course also depends upon the extent to which tax revenues collected by states by surtaxes are included in the fiscal equalization system.
} 
One should expect that in the case of tax autonomy $s$ is fixed such that $s \leq 0.425 \tau$. Thus the effective state income tax rate $s+t_{i}$ can be both smaller as well as larger as $s$ because it might be possible that some states set $t_{i}<0$. In addition, we take $s$ as an indicator of the intensity of tax autonomy. If states are granted the right to collect a surtax on the federal income tax rate and the surtax is restricted to the range say $+/-20 \%$ as compared to a range of say $+/-10 \%$, in the former case a smaller share of income tax revenues of states would be included in the fiscal equalization system. In an extreme version which is also discussed in Germany - all income taxes accrue to the state level and states fix income tax rates autonomously and $s$ could be set equal to zero. In this case income tax revenues are completely disregarded in the fiscal equalization system. Alternatively one can set $s$ equal to some fictious value in the range $0<s<0.425 \tau{ }^{16}$ The crucial point is, that the parameter $s$ is independent of $t_{i}$ and thus income tax revenues of state $i$ included in the fiscal equalization system are not affected by state's $i$ income tax policy. Because in our subsequent model it is not possible to compare the current situation - no taxing authority of states - with the reform model - the power to tax income - we use the parameter $s$ to evaluate the impact of varying degrees of tax autonomy on fiscal outcomes. ${ }^{17}$

We model two types of expenditures. The first type are program expenditures which we denote - in per capita terms - by $g_{i}$. In addition we introduce a fixed cost component, $a_{i}$, for which we offer two interpretations. $a_{i}$ can be interpreted as the fixed cost of running states - such as the cost of the general administration infrastructure ${ }^{18}$ - or alternatively, $a_{i}$ can be interpreted as cost inherited from past decisions, such as interest payments on state public debt and pension payments on retired public servants. Thus total expenditures in state $\mathrm{i}$ are simply defined by $a_{i}+m_{i} g_{i}$. As we will show in our empirical part both interest and pension payments are quite important and per capita spending in fiscally weak states is significantly higher as compared to fiscally stronger states.

Private households have the simple budget restriction:

$$
c_{i}=\left(1-s-t_{i}\right) y_{i} \text {. }
$$

with $c_{\mathrm{i}}$ denoting spending on a private consumption good. State governments seek to maximize the welfare function ${ }^{19}$

$$
W_{i}=\left(g_{i}-\bar{g}\right)^{\beta} c_{i}^{1-\beta} \quad 1<\beta<1 .
$$

subject to the budget restriction

$$
a_{i}+m_{i} g_{i}=m_{i}\left(s+t_{i}\right) y_{i}+m_{i} z_{i}
$$

which is given in per capita terms as:

$$
a_{i} / m_{i}+g_{i}=\left(s+t_{i}\right) y_{i}+z_{i} .
$$

\footnotetext{
${ }^{16}$ In the latter case it might occur that income tax revenues of state $i$ taken into account in the fiscal equalization system exceed effective income tax revenues if state $\mathrm{i}$ has a very low income tax rate such that $\mathrm{s}+\mathrm{t}_{\mathrm{i}}<\mathrm{s}$.

${ }^{17}$ In an early paper, Musgrave (1961) addressed the issue of fiscal equalization and state tax autonomy.

${ }^{18}$ This interpretation would coincide with issues discussed by Tullock (1969).

${ }^{19}$ Fuest (2008) uses the welfare function $\mathrm{W}_{\mathrm{i}}=\mathrm{h}\left(\mathrm{g}_{\mathrm{i}}\right)+\mathrm{u}\left(\mathrm{c}_{\mathrm{i}}\right)$.
} 
Note that our welfare function is of the Stone-Geary type ${ }^{20}$ and incorporates a minimum standard of per capita public good provision, $\bar{g}$. The welfare function (4) should not be looked upon as the utility function of households because households also derive utility from public service provision $g_{i}<\bar{g}$. Equation (4) is interpreted by us as the welfare function policy makers have in mind and we argue that in the political competition process policy makers only gain a competitive advantage if public service provision exceeds the amount $\bar{g}$. Alternatively one could incorporate $g_{i}$ rather than $\left(g_{i}-\bar{g}\right)$ in the welfare function and specify an additional restriction $g_{i}>\bar{g}$ to take minimum standards into account. Our specification is a simplified version which facilitates the derivation of simple closed-form solutions.

The public good $g_{i}$ has the property of a publicly provided private good and for the sake of simplicity we call the expenditures $g_{i}$ primary expenditures. We believe that the specification of a minimum standard in public good provision is both a meaningful as well as realistic assumption especially in Germany because the German Constitution asks for the achievement of "equal living condition" as has been discussed in section 2. Even if one disregards this special Constitutional condition in Germany, one should expect that in virtually all areas of policy states have to meet a minimum standard of public good provision. State government cannot freely adjust the provision of public services because political factors as well as social norms in the society ask for certain standards in schools, the tax administration, police forces, courts, etc. In addition, regulations by federal law as well as by EU laws significantly affect state policy ranging from environmental protection policy up to the support of schooling and cultural activities of minorities. ${ }^{21}$ Taking minimum standards in account total public expenditures at the state level can be written as:

$$
\text { state expenditures }=a_{i}+m_{i} \bar{g}+m_{i}\left(g_{i}-\bar{g}\right) \quad \mathrm{g}_{\mathrm{i}} \geq \bar{g}
$$

The first two expenditure components are virtually beyond the control of state government, at least in the short-run and medium-run. Pension payments for retired public servants can be manipulated only within a time horizon of more than 20 years and it also takes a considerable time to reduce state debt and thus achieve significant savings in interest expenditures. ${ }^{22}$

\footnotetext{
${ }^{20}$ It would be more appropriate to specify the welfare function in the form $W_{i}=A\left(x_{i}\right)\left(g_{i}-\bar{g}\right)^{\beta} c_{i}^{1-\beta}$ with $\mathrm{A}(.$. denoting an amenity factor and the vector $x_{i}$ includes a wide range of state specific and utility creating characteristics (such as the landscape, cultural ties etc.) because without these additional factors the currently observed distribution of the population across states would not be consistent with an equilibrium. However, because we do not take into account migration flows we disregard the issue of the equilibrium distribution of the population and thus can stick to our simple specification.

${ }^{21}$ Using a data set of program specific expenditures we estimated that about $20 \%$ of state primary expenditures are directly determined by EU programs and federal standards, see Seitz (2008b).

${ }^{22}$ Recent reforms in Germany tried to reduce the impact of federal standards on state expenditures but taking the constitutional constraints of achieving "equal living conditions" into account, these reforms have been rather modest and did not result in a dramatic decrease in $\bar{g}$.
} 


\section{Results}

Making the usual Cournot assumption, that means, states do not take into account fiscal externalities induced by own actions on other states, we derive the following optimality condition by maximizing (4) subject to (3) and (5'):

$$
y_{i}-\frac{a_{i}}{m_{i}}\left(\frac{d m_{i}}{d t_{i}} \frac{1}{m_{i}}+\frac{\partial m_{i}}{\partial g_{i}} \frac{1}{m} \frac{d g_{i}}{d t}\right)-\frac{(1-\beta)\left(g_{i}-\bar{g}\right)}{\beta\left(1-s-t_{i}\right)}=0 .
$$

The effect $d g_{i} / d t_{i}$ is derived from the government budget restriction (5') and is given by:

$$
\frac{d g_{i}}{d t_{i}}=\frac{1-\frac{a_{i}}{g_{i} m_{i}} \eta_{m, g}}{y_{i}+\frac{a_{i}}{t_{i} m_{i}} \eta_{m, t}}>0 .
$$

with $\eta_{m, g}>0$ bzw. $\eta_{m, t}<0$ denoting the elasticity of the population with respect to the provision of public services and the state surtax. To ensure $d g_{i} / d t_{i}>0$ we need stability conditions similar to those derived by Zodrow and Mieszkowski (1986). A positive denominator requests $\left|t_{i} m_{i} y_{i}\right|>\left|a_{i} \eta_{m, t}\right|$ and a positive nominator we get under the assumption $g_{i} m_{i}>a_{i} \eta_{m, g}$. Both conditions are met if we assume that fixed costs $a_{i}$ are not unreasonable high and both elasticities do not take on implausible high (absolute) values.

Empirical research suggests, see Kirchgässner and Pommerehne (1996), Feld and Kirchgässner (2001), or Feld (2000), Liebig and Sousa-Poza (2006) or Liebig, Puhani and Sousa-Poza (2007), that the impact of tax competition on interregional migration flows of households is rather small. Feld and Frey (2000) even argue, that the marginal impact of differences in personal income taxes between the Swiss cantons on interregional migration flows of households makes it possible to run redistributive politics at the subnational government level. If we take a closer look at equation (7) we see that the terms $\mathrm{dm}_{\mathrm{i}} /\left(\mathrm{dt}_{\mathrm{i}} \mathrm{m}_{\mathrm{i}}\right)^{23}$ and $\mathrm{dm}_{\mathrm{i}} /\left(\mathrm{dg}_{\mathrm{i}} \mathrm{m}_{\mathrm{i}}\right)$ are the relative change in the size of the population induced by a marginal increase in $t_{i}$ and $g_{i}$ and one should expect that both effects are rather small numerically. In addition, both effects are counter directed and thus there are neutralizing forces at work. Therefore we follow the assumption of Fuest (2008) and neglect the impact of tax competition between states on the distribution of households as well as on income across states, an assumption that should hold at least in the short-run and medium-run.

Under these simplifying assumption we get a very simply equation for state surtaxes:

$$
t_{i}=(\beta-s)+\frac{1-\beta}{y_{i}}\left(\bar{g}+\frac{a_{i}}{m_{i}}-z_{i}\right) .
$$

\footnotetext{
${ }^{23}$ We use semi-elasticities because using elasticities would make it necessary to expand the equation with $t_{i}$ and we would receive a nonlinear equation in $\mathrm{t}_{\mathrm{i}}$ !
} 
The state surtax $t_{i}$ can be both positive as well as negative and we can derive the following properties:

a) $\quad d t_{i} / d \bar{g}=(1-\beta) / y_{i}>0$, that is, an increase in minimum standards puts an upward pressure on state surtaxes.

b) $\quad d t_{i} / d s_{i}<0$, that is, an increase in the federal tax rate reduces the state surtax. As we discussed above, we take $s$ as an indicator of the degree of taxing autonomy of states arguing that an increase in taxing autonomy drives down $s$ and thus more taxing autonomy leads to an increase in the surtax.

c) The impact of the fiscal equalization parameter $b$, which determines the intensity of the revenue equalizing effect of the equalization system, depends upon the fiscal capacity of state i. For fiscally weak states, $y_{i}<\bar{y}, d t_{i} / d b$ is negative whereas the effect is positive for fiscally strong states.

d) An increase in $a_{i}$ is positive and stronger for fiscally weaker states $\left(y_{i}<\bar{y}\right)^{24}$ as well as for smaller states $\left(\mathrm{m}_{\mathrm{i}}<\bar{m} \text {, with } \bar{m} \text { denoting the average size of states }\right)^{25}$ because $\frac{d t_{i}}{d a_{i}}=\frac{1-\beta}{m_{i} y_{i}}$ and thus $\frac{\frac{d t_{i}}{d a_{i}}}{d y_{i}}<0$ and $\frac{\frac{d t_{i}}{d a_{i}}}{d m_{i}}<0 .^{26}$

However, our theoretical model does not make it possible to derive general conclusions with respect to the question, whether fiscally strong or weak states set higher surtaxes. To examine the issue further we derive the surtax differential between a fiscally weak and fiscally strong state. To achieve this, we assume that both states are of equal size $m$. For fiscally weak state we approximate income by $y_{u}=$ $\bar{y}(1-\lambda)$ and fixed cost by $a_{u}=a(1+\lambda)$ whereas for the fiscally strong state we assume $y_{h}=\bar{y}(1+\lambda)$ and $a_{h}=a(1-\lambda)$. The index $\mathrm{u}$ indicates a fiscally weak state whereas the index $\mathrm{h}$ indicates a fiscally strong state. The parameter $\lambda, 0<\lambda<1$, measures the relative difference in income between both states and the larger the parameter $\lambda$ the larger are the differences between the fiscal capacities of both states. As we will show in the empirical part of the paper, in Germany fiscally weak states have a significantly larger per capita fiscal burden in terms of per capita interest payments as well as per capita spending on pension payments for retired public servants as compared to fiscally strong states. This empirical fact justifies our assumption $a_{u}>a_{h}$.

Using these assumptions as well as the assumption of equally sized states, $m=m_{u}=m_{h}$, we get the following expression for the surtax difference between both states:

\footnotetext{
${ }^{24}$ Assuming fiscally strong and weak states to be of equal size.

${ }^{25}$ Assuming big and small states to have identical fiscal capacities.

${ }^{26}$ In passing we note that the last effects indicates an impact of demographics - measured in terms of population size - on state surtaxes. This is of significant importance in Germany because the states in East Germany are forecasted to lose more $10 \%$ of their population in the next 25 years. Thus, demographic change puts an upward pressure on state surtaxes in East Germany. Because the fiscal capacity of all East German states is significantly smaller than the fiscal capacity of the fiscally weakest states in West Germany, this result is of quite significance in the discussion on taxing autonomy for states in Germany.
} 


$$
t_{u}-t_{h}=\frac{(1-\beta) 2 \lambda}{1-\lambda^{2}}\left(\frac{\bar{g}}{\bar{y}}+\frac{2 a}{m \bar{y}}-b\left(s+t^{d}\right)\right)
$$

If there would be no fiscal equalization system $(b=0)$ fiscally weak states would have to charge a higher surtax. If there is a fiscal equalization system the difference between the two surtaxes depends upon the degree of fiscal equalization (parameter $b$ ) as well as the share of tax revenues included in the fiscal equalization system $\left(s+t^{d}\right)$. An increase in $b$ or $s+t^{d}$ increases the probability that fiscally strong states have higher surtaxes as compared to fiscally weak states. On the other hand, increasing values of $\bar{g}$ as well as per capita fixed cost work in the opposite direction.

We evaluated the size of the term $\left(\frac{\bar{g}}{\bar{y}}+\frac{2 a}{m y}-b\left(s+t^{d}\right)\right)$ in equation (10) using average data for the fiscal year 2007. In 2007 the volume of taxes included in the fiscal equalization system amounted to about $10 \%$ of GDP, which we take as a proxy for $s+t^{d}$. The parameter $b$ in the German fiscal equalization system is rather high, see Baretti, Huber and Lichtblau (2002) as well as our presentation in section 2, and has been set to 0.9. Average state per capita expenditures amounted to about 3,200€. To estimate per capita fixed cost we add average per capita spending on pensions for retired public servants $(230 €)$ and interest rate payments $(270 €)$. Average per capita GDP amounted to about $29,950 €$ and we assume that $75 \%{ }^{27}$ of primary expenditures - total per capita expenditures minus per capita fixed costs - are determined by minimum standards. Thus $\bar{g} / \bar{y}$ is about 0.072 and $2 a /(m \bar{y})$ about 0,033 . Using these benchmark values we evaluate the term in brackets to be about +0.011 in which case fiscally weak states have a higher surtax as compared to fiscally strong states. In our estimate the critical assumption is the percentage of primary expenditures predermined by minimum standards. Therefore we checked the critical value of $\bar{g}$ that produces an estimate of 0 for the bracket term. This critical value is reached if about $65 \%$ of public primary expenditures are determined by minimum standards. ${ }^{28}$ In section 4 we provide evidence that in Germany the importance of minimum standard spending is well above this ratio.

In a similar way - using the same assumptions - we look at differences in the provision of public services between fiscally weak and strong states. First we derive optimal primary expenditures:

$$
g_{i}=\beta\left(y_{i}+z_{i}-\bar{g}-\frac{a_{i}}{m_{i}}\right)+\bar{g},
$$

\footnotetext{
${ }^{27}$ In section 4 we derive this figure as a rough estimate!

${ }^{28}$ Because in the fiscal equalization system in Germany also a significant share of tax revenues of the local government sector within each state is included, the estimate of $s+t^{d}$ is upward biased and we therefore underestimate the critical level of $\bar{g}$.
} 
The term in parenthesis is "disposable" revenue after paying for fixed cost and minimum standards and thus $g_{i}-\bar{g}$ denotes the volume of per capita primary spending under the discretion of state governments. Using equation (11) we can calculate the difference in public service provision between a fiscally weak $\left(g_{u}\right)$ and a fiscally strong $\left(g_{h}\right)$ state which yields the following equation:

$$
g_{u}-g_{h}=-2 \beta \lambda\left(\left(1-b\left(s+t^{d}\right)\right) \bar{y}+\frac{a}{m}\right)<0
$$

As a matter of course it is not surprising that this difference is negative - independently of the impact of taxing autonomy - because states with a lower tax base can afford only a lower supply of public services. This difference is reduced if $b$ increases or if $\lambda$ decreases. Because in a taxing autonomy regime the term $b\left(s+t^{d}\right)$ has to be smaller as compared to a system without taxing autonomy, the difference in public service provision increases if the degree of state tax autonomy increases.

\section{Results of model simulations}

To complement our theoretical analysis we did some simulations to study the impact of the two key elements of our theoretical model, fixed cost and minimum standards. Our simulation considers two states which differ only with respect to the average income. For the fiscally weak state we assume $y_{u}=$ 8.000 whereas for the fiscally strong states $y_{h}=12.000$. The other parameters are fixed as follows:

$$
\beta=0.2 \quad t^{d}=0.05 \quad s=0.15 \quad b=0.9 \quad m_{u}=m_{h}=100 \quad a_{u}=a_{h}=10,000 \quad \bar{y}=10,000
$$

In a first simulation model we examine the sensitivity of state surtaxes on alternative assumptions about minimum standards. This we achieve by steadily increasing $\bar{g}$ in both states and thus we assume that an increasing share of primary expenditures, which we measure in terms of $g_{i}$, are predermined by minimum standards.

The results of our simulations are depicted in figure 1. If there are no minimum standards, the fiscally weak state collects a smaller surtax as compared to the fiscally strong state, a result that is consistent with Fuest (2008), who does not take minimum standards into account. However, with an increasing importance of minimum standards the surtax of the fiscally weak state increases faster than the surtax in the fiscally strong state. In our simulation the surtax lines of both states intersect if $\bar{g}=1.700$. In this case, in the fiscally weak state about $56 \%$ and in the fiscally strong state about $46 \%$ of primary expenditures $\left(\bar{g} / g_{i}\right)$ are determined by minimum standards. 
Figure 1: Surtaxes in fiscally weak and fiscally strong states with alternative assumptions on the importance of minimum standards
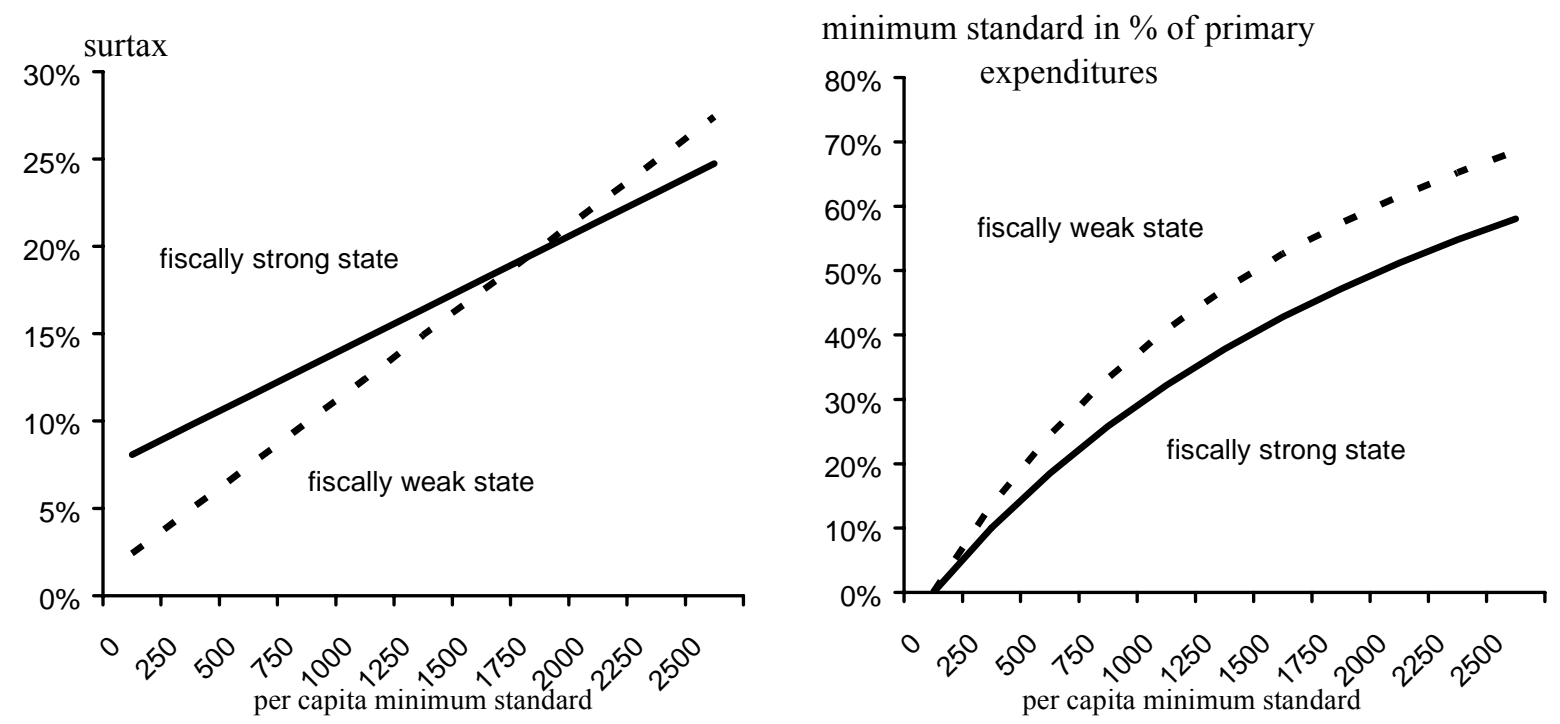

Source: Calculations by the author.

We also note the following property: If both countries are of the same size, $\mathrm{m}_{\mathrm{u}}=\mathrm{m}_{\mathrm{h}}$ and fixed cost are identical, $a_{u}=a_{h}$, the critical level of $\bar{g}$, where the surtax lines of the fiscally weak and strong states intersect, is independent of the income difference between both states! Tedious algebra reveals that this critical level is given by $\bar{g}^{c}=\overline{b y}\left(s+t^{d}\right)-\frac{a}{m}$. Thus fiscally weak states always have a higher surtax as compared to fiscally strong states if $\bar{g}>\bar{g}^{c}$ under the above mentioned conditions. In addition, we see that the "critical level" of minimum standards is decreasing in taxing autonomy (measured in our interpretation in terms of a smaller value of $s$ ) as well as in fixed cost.

In a second simulation experiment we examine the impact of fixed cost on public good provision between both states. We assume the same parameters as above and take $\bar{g}=1.700$, which we identified in figure 1 as the critical value of per capita minimum standards where the surtax lines of both states intersect and thus both states have an identical tax rate. Next we vary $a_{u}$ in the fiscally weak state keeping $a_{h}$ in the fiscally strong state constant. The results are shown in figure 2 and indicate that an increase in fixed cost puts upward pressure on surtaxes. This issue is of significant importance for the current debate on introducing taxing autonomy at the state level in Germany. In Germany states with a far above average fiscal burden of the past - as for example above average interest payments - argue that the "starting conditions" for entering a regime of taxing autonomy are rather heterogeneous and force states with above average inherited fixed costs to collect higher surtaxes which creates a significant disadvantage in the tax competition process that will result under 
taxing autonomy. Our results from the theoretical investigation as well as our simulation experiments suggest that this issue is indeed of significant importance.

Figure 2: Surtaxes in fiscally weak and fiscally strong states assuming $\bar{g}=1.700$ in both states with a varying size of fixed cost in the fiscally weak state
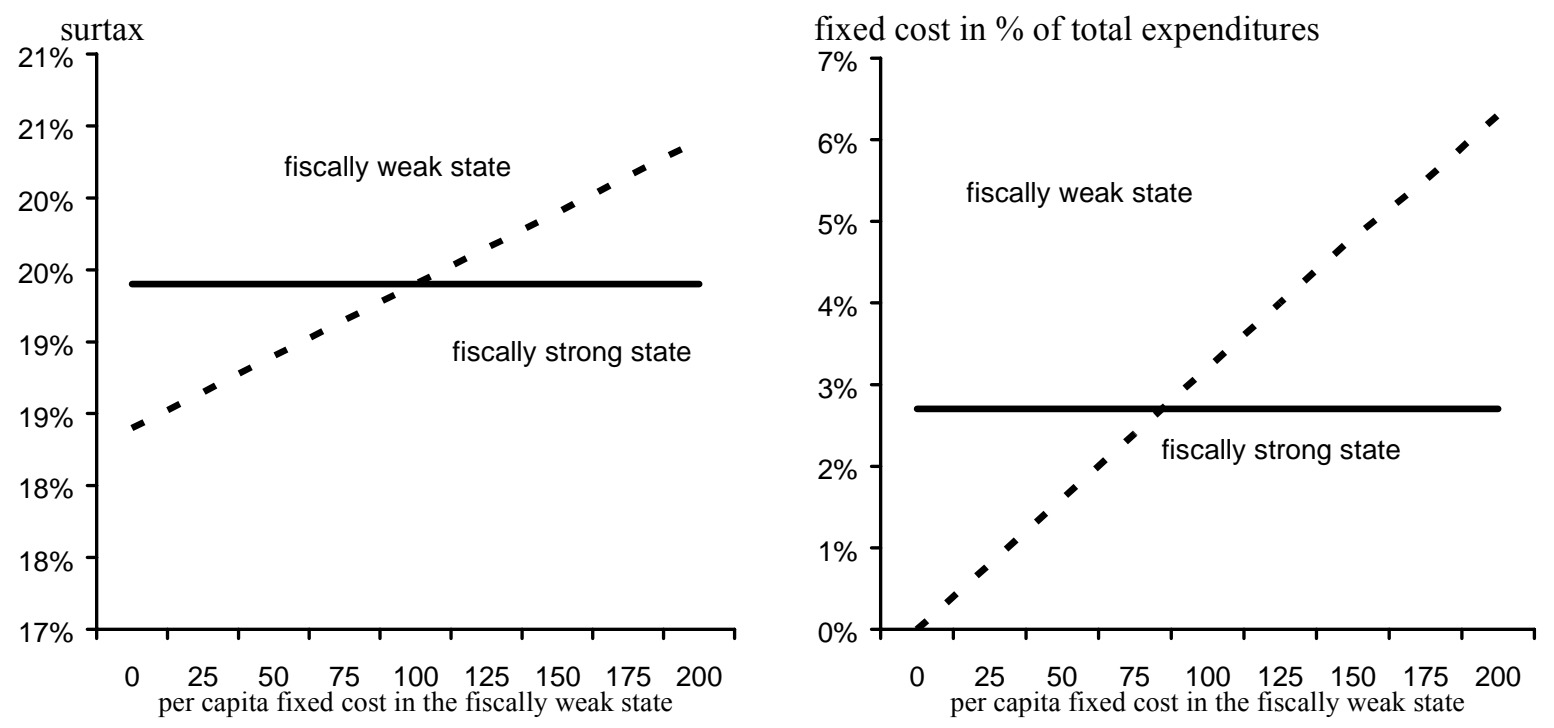

Source: Calculations by the author.

\section{Summarizing and discussing the relevance of the results}

Our theoretical investigation as well as our simulation experiments stress the importance of minimum standards and the inherited public burden, such as public debt, if a federal system changes from a "no tax autonomy regime" to a "tax autonomy regime". The arguments put forward support the conclusion drawn by Jourmard and Kongsrud (2003, p. 188), that jurisdictions with a poor taxing capacity might find it hard to secure a minimum or average standard of public goods supply in a tax autonomy regime. As a matter of course, the strong impact of minimum standards does not come as a surprise. Models that disregard minimum standards implicitly assume a virtually perfect upward and downward flexibility of public service provision which is by no means realistic. In virtually all policy areas, governments have to provide a minimum level of public services. ${ }^{29}$

Minimum standards have many reasons. There are Constitutional and legal restrictions (such as in the area of environmental protection measures), social and political norms, as well as in the political competition between parties that promise to increase the number of policemen or the number of teachers in schools etc in election campaigns. As a matter of course, neither in Germany nor in any

${ }^{29}$ Ensuring minimum standards in the provision of public services provides a key motivation for fiscal equalization systems in federal states. 
other country, there are legally binding rules for a minimum number of policemen per 100,000 inhabitants or the number of school teachers per 100 pupils. However, every government that tries to reduce public service provision below some minimum benchmark values in areas of political sensitivity - such as in the police force or in schools - will face very stiff competition both in parliament as well as in the media or even on the street. This pressure holds for both fiscally strong as well as fiscally weak states in Germany. One can assume similar conditions in many other (at least European) countries. As a matter of course, there are other instruments at hand to respond to high minimum standards, as for example wages of public servants. Indeed, in Germany recent reforms increased the discretion of states on pay determination in the public sector. However, taking into account the strong power of trade unions the effective room for maneuver of state governments gained by these reforms is rather small. Consequently, there is significant pressure on fiscally weak states to keep up with fiscally strong states in the provision of public services because of the political pressure to provide similar public services levels and to stick to the Constitutional norm of "equal living conditions".

\section{Empirical facts}

Our theoretical model has three important ingredients that we tailored to the institutional settings in Germany: The fiscal equalization system, state fixed cost and minimum standards. In this section we present empirical evidence on the importance of these factors.

\section{Distributional effects of introducing taxing autonomy at the state level}

We use the fiscal equalization system in 2007 to examine the distributional impact of introducing taxing autonomy at the state level disregarding all medium- and long-run effects that might result out of tax competition between German states. ${ }^{30}$ Therefore our results depict short-and medium-run effects.

In a first step we reduce the federal income tax rate such, that income tax revenues that accrue to the state level are reduced by $10 \%$.

In a second step states impose surtaxes on the federal income tax collection such that states receive the same additional income tax revenues that were lost in the first step because of the reduction in the federal income tax rate.

\footnotetext{
${ }^{30}$ See Büttner and Schwager (2003) for similar calculations.
} 
In a third step we calculate the distributional impact of step one and step two taking into account the fiscal equalization system in Germany assuming that all tax revenues collected in step 2 are excluded from the fiscal equalization system.

Table 3 reports our results using data and institutional settings in 2007. In the state NordrheinWestfalen the reduction in the federal income tax rate would create a loss of $86 €$ per capita in step 1 which is compensated by a surtax on federal income tax payments by the same amount. However, Nordrhein-Westfalen is a fiscally strong state and has to make payments in the fiscal equalization system which are now significantly reduced because tax revenues collected from the surtax are not taken into account in the fiscal equalization system. This results in an increase in total state revenue tax revenue net of fiscal equalization transfers - by about $8 €$ per capita. For comparison we look at the East German state Sachsen. In step one the state Sachsen would lose $33 €$ per capita which is compensated in step two. However, transfer payments of fiscally strong states are reduced because revenues collected from the surtax are not taken into account in the fiscal equalization system and consequently the state Sachsen would lose a total of $46 €$ per capita.

Table 3: Distributional effects of taxing autonomy of German states: Simulation results for the fiscal year 2007

\begin{tabular}{|l|r|r|r|r|}
\hline & \multicolumn{2}{|c|}{$\begin{array}{c}\text { additional revenues } \\
\text { from income surtax }\end{array}$} & \multicolumn{2}{c|}{$\begin{array}{c}\text { Change in total tax reveues after } \\
\text { fiscal equalization }\end{array}$} \\
\hline & \multicolumn{1}{|c|}{ Mill. $€$} & $\begin{array}{c}€ \text { per } \\
\text { capita }\end{array}$ & \multicolumn{2}{c|}{ Mill. $€$} \\
$€$
\end{tabular}

Source: Calculations by the author.

One might wonder, whether these effects are of significant importance in a political discussion. However, in the period 2000 - 2001, due to a ruling of the Constitutional Court, the fiscal equalization system in Germany had to be reformed and the reform discussion was almost exclusively dominated 
by distributional issues. The prime ministers of all German states made a decision that the distributional effects of reforming the fiscal equalization system in Germany has to stick to distributional effects not exceeding the interval of $+/-6 €$ per capita. Our calculation in table 3 suggest distributional effects in the range of $-46 €$ to $+21 €$ per capita and thus one should expect that any discussion on state taxing autonomy in Germany would be severely hampered by distributional effects that arise out of this change in policy.

In a final step we calculate the surtax each state would have to apply if all distributional effects are neutralized. As can be seen from the last column of table 3, fiscally strong states will have surtaxes that are lower than the initial cut in the federal income tax rate whereas the reverse holds true for fiscally weak states. Figure 3 reports our results. Whereas fiscally strong states have surtaxes ranging from $8.1 \%$ to $9.1 \%$ the fiscally weak states in West Germany need surtaxes in the range of $10.2 \%$ up to $13.2 \%$. In the East German states these surtaxes are much higher ranging from $19 \%$ to $24.3 \%$.

Figure 3: Surtaxes at the state level in Germany in the year 2007 necessary to achieve distributional neutrality ${ }^{1}$

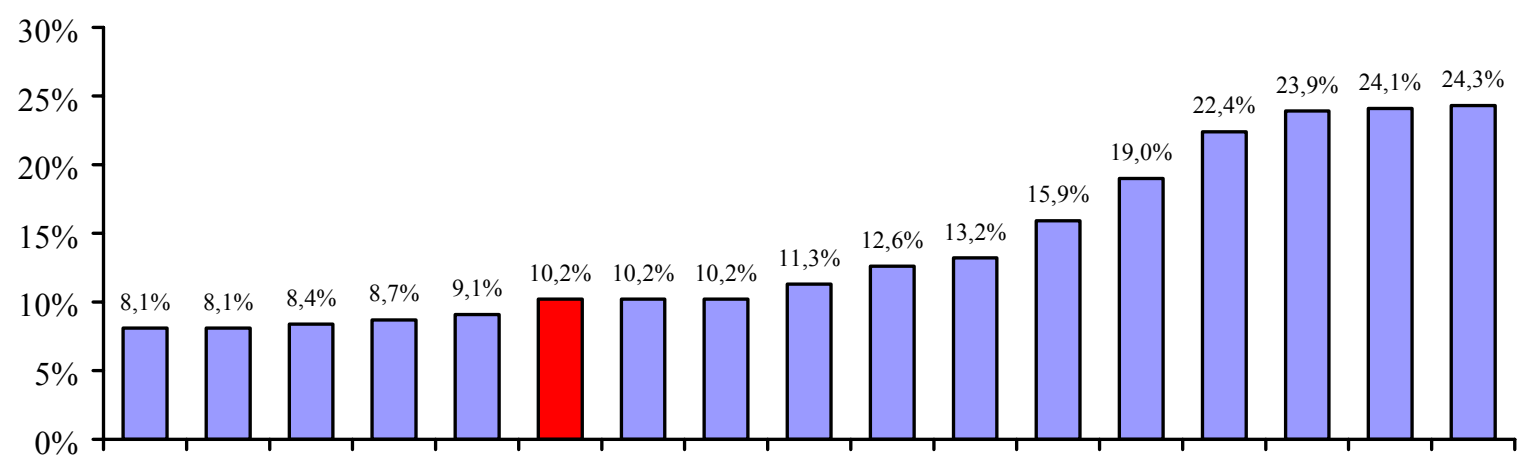

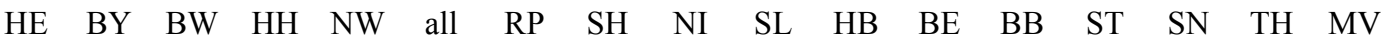

${ }^{1}$ For state abbreviations see table 3.

Source: Calculations by the author.

As a matter of course, such differences in surtaxes would be impossible to handle politically inside and outside Germany. In addition, policy makers in fiscally weak states would not be able to convince their citizens that surtaxes have to be larger as compared to surtaxes in fiscally stronger states. Consequently, fiscally weak states would not be able to compensate the negative distributional effects by an appropriate tax policy and would therefore have to reduce the provision of public services. Because the latter is almost as difficult to achieve in the political process as the setting of an aboveaverage tax rate, it is not surprising that there is stiff opposition of politicians from fiscally weak states against taxing autonomy at the state level in Germany. 
Apart from minimum standards the fixed cost parameter $a_{i}$ played a crucial role in the theoretical model. We interpreted fixed costs in terms of interest payments and pensions for retired public servants. Both expenditures are due to decision made in the past and are hard to manipulate by policy makers at least in the short- and medium run. In table 4 we show the fiscal burden associated with these two expenditure items and for comparison we also report transfers made and subsidies received in the fiscal equalization system.

Table 4: Per capita expenditures on interest payments and pensions for retired public servants as well as per capita transfers provided (-) and received (+) in the fiscal equalization system in $2007^{1}$

\begin{tabular}{|l|r|r|}
\hline & $\begin{array}{c}\text { Per capita expenditures on } \\
\text { interest payments and } \\
\text { pensions for retired public } \\
\text { servants }\end{array}$ & $\begin{array}{c}\text { Per capita transfers provided } \\
(-) \text { and received by states in } \\
\text { the fiscal equalization system } \\
\text { including VAT redistribution }\end{array}$ \\
\hline \multicolumn{3}{|c|}{ West German area states } \\
\hline Hessen (HE) & 511 & -644 \\
\hline Baden-Württemberg (BW) & 441 & -359 \\
\hline Bayern (BY) & 332 & -336 \\
\hline Nordrhein-Westfalen (NW) & 512 & -158 \\
\hline Niedersachsen (NI) & 532 & 78 \\
\hline Schleswig-Holstein (SH) & 603 & -5 \\
\hline Rheinland-Pfalz (RP) & 520 & 28 \\
\hline Saarland (SL) & 738 & 225 \\
\hline & \multicolumn{2}{|c|}{569} \\
\hline Sachsen-Anhalt (ST) & East German states & 776 \\
\hline Brandenburg (BB) & 500 & 749 \\
\hline Sachsen (SN) & 307 & 843 \\
\hline Thüringen (TH) & 493 & 885 \\
\hline Mecklenburg-Vorpommern (MV) & 465 & 922 \\
\hline \multicolumn{3}{|c|}{ City states } \\
\hline Hamburg (HH) & 1.078 & -363 \\
\hline Bremen (HB) & 1.371 & 553 \\
\hline Berlin (BE) & 1.130 & 933 \\
\hline
\end{tabular}

${ }^{1}$ In the East German states as well as Berlin special pension payments that are due to inherited pension obligations from the former GDR (AAÜG) are included.

Source: Calculations by the author.

In comparing data for the East and West German states one has to take into account that due to the short history of the East German states, figures for the East and West German states are not comparable. If we look at the West German area states we note that per capita spending on interest payments and pensions for retired public servants in fiscally weak states significantly exceed expenditures in fiscally strong states. Whereas fiscally weak states in West Germany have per capita spending of about $600 €$ in the fiscally strong states these expenditures amount to only about $450 €$. This evidence supports our assumptions made in the theoretical part, namely that fiscally weak states have systematically higher per capita fixed costs as compared to fiscally strong states. The bulk of 
these differences in per capita expenditures are caused by interest payments whereas per capita expenditures on pension payments for retired public servants are rather similar within West German and within East German states.

In figure 4 we depict the annual increase in per capita public debt in the West German ${ }^{31}$ fiscally strong and fiscally weak states. ${ }^{32}$ In the period 1980 - 2007 the increase in per capita public debt in fiscally weak states was on the average about $50 \%$ larger as compared to the fiscally strong states. As we argued elsewhere, see Seitz (2008a), the above average per capita debt might be due to political disincentives that provoke policy makers in fiscally weak states to mimic public service provision in the fiscally strong states despite lower per capita revenues.

Figure 4: Annual increase in per capita debt of fiscally weak and fiscally strong states in Germany 1980 - 2007 in $€$ per capita

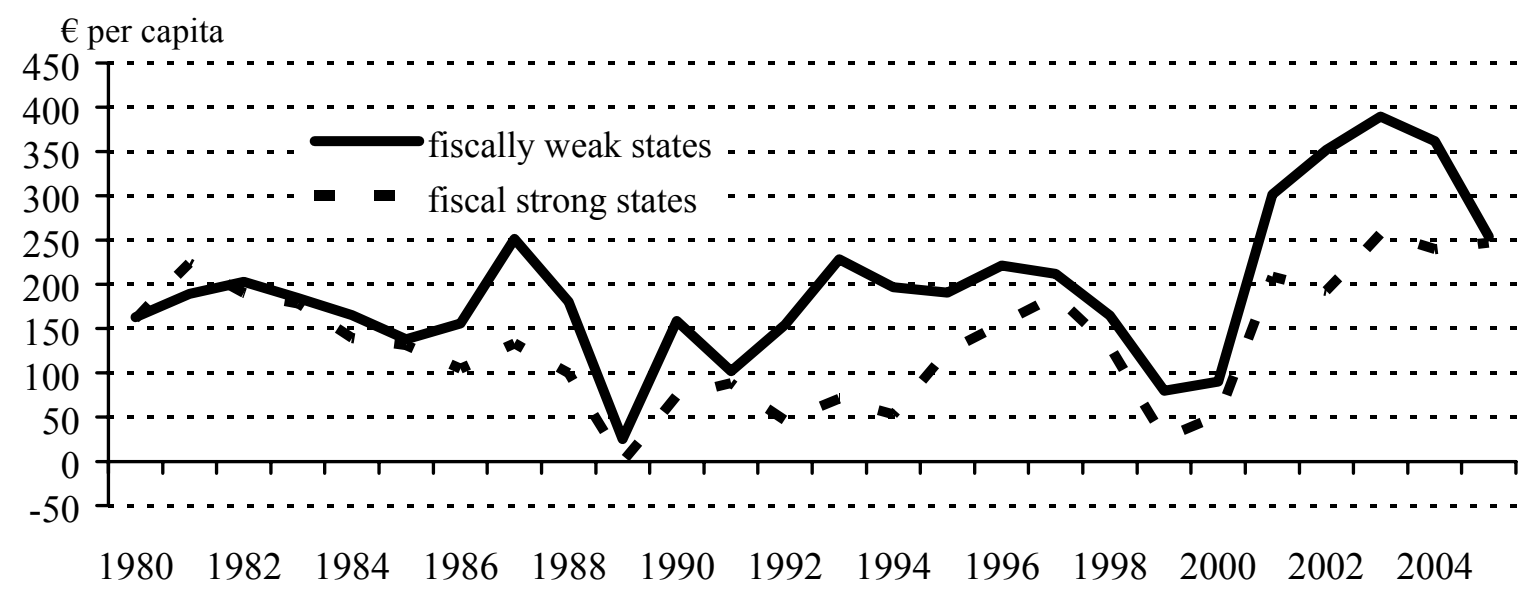

Source: Calculated from data supplied by the Federal Statistical Office, Wiesbaden, Germany.

A rough estimate of the importance of minimum standard spending

There is no data available from which we can derive empirical evidence on the importance of minimum standards at the state level in Germany directly. However, we tried to derive a rough estimate of minimum standard spending using data on West German states for the year $2005 .{ }^{33}$ To achieve this, we calculated the average per capita expenditures as well as the minimum per capita expenditures in the West German states in each function. This procedure we carried out both at the state level as well as at the aggregate of the state and local government sector in each state. The latter calculations have been done because the division of tasks between the state and local government level

\footnotetext{
${ }^{31}$ Excluding the city state Hamburg.

${ }^{32}$ Excluding the city state Bremen as well as the state Saarland because both states received considerable bailout transfers in the period $1994-2004$.

${ }^{33}$ Because the East German states have a quite different per capita spending level as well as expenditure structure because of the still ongoing adjustment process in East Germany, we refrained from using East German data.
} 
varies significantly across states. Because each state has to provide compulsory transfers to the local government sector, fixed in the Constitution of each state, which depend upon the fiscal capacity of the state and the local government sector as well as the division of tasks between both levels of government, for state governments it does not matter whether minimum standards have to be met at the state or at the local government sector because state government have to pay for it directly - own expenditures - or indirectly - by providing transfers to local governments.

Table 5: Estimate of the importance of minimum per capita spending in Germany in 2005

\begin{tabular}{|c|c|c|c|c|c|c|c|}
\hline & \multicolumn{3}{|c|}{ state level } & \multicolumn{3}{|c|}{ state and local government level } \\
\hline & & $\begin{array}{l}\text { average } \\
\text { p.c. } \\
\text { spending }\end{array}$ & $\begin{array}{l}\text { minimum } \\
\text { in \% of } \\
\text { average }\end{array}$ & $\begin{array}{l}\text { minimum } \\
\text { p.c. } \\
\text { spending }\end{array}$ & $\begin{array}{l}\text { average } \\
\text { p.c. } \\
\text { spending }\end{array}$ & $\begin{array}{l}\text { minimum } \\
\text { in \% of } \\
\text { average }\end{array}$ & $\begin{array}{l}\text { minimum } \\
\text { p.c. } \\
\text { spending }\end{array}$ \\
\hline & & (1a) & $(2 a)$ & $(3 a)$ & (1b) & $(2 b)$ & $(3 b)$ \\
\hline 1 & General administration & 144 & $65 \%$ & 94 & 351 & $80 \%$ & 281 \\
\hline 2 & tax administration & 92 & $90 \%$ & 83 & 135 & $92 \%$ & 124 \\
\hline 3 & Public order \& safety & 200 & $92 \%$ & 184 & 299 & $93 \%$ & 278 \\
\hline 4 & Jurisdiction \& prisons & 174 & $75 \%$ & 130 & 174 & $86 \%$ & 150 \\
\hline 5 & Schools & 654 & $90 \%$ & 589 & 813 & $89 \%$ & 723 \\
\hline 7 & Universities & 310 & $76 \%$ & 236 & 310 & $76 \%$ & 236 \\
\hline 8 & $\begin{array}{l}\text { Financial support to } \\
\text { students }\end{array}$ & 47 & $20 \%$ & 9 & 69 & $20 \%$ & 14 \\
\hline 9 & All other education & 21 & $49 \%$ & 10 & 29 & $66 \%$ & 19 \\
\hline 10 & Research & 44 & $62 \%$ & 27 & 48 & $75 \%$ & 36 \\
\hline 11 & Culture & 58 & $32 \%$ & 19 & 124 & $69 \%$ & 85 \\
\hline 12 & Social Welfare $^{1}$ & 441 & $90 \%$ & 344 & 1.097 & $90 \%$ & 856 \\
\hline 13 & $\begin{array}{l}\text { Health/environmental } \\
\text { protection }\end{array}$ & 98 & $60 \%$ & 59 & 198 & $81 \%$ & 160 \\
\hline 14 & $\begin{array}{l}\text { Housing \& community } \\
\text { amenities }\end{array}$ & 78 & $68 \%$ & 53 & 346 & $68 \%$ & 235 \\
\hline 15 & Agriculture \& forestry & 67 & $46 \%$ & 31 & 70 & $45 \%$ & 31 \\
\hline 16 & Fuel \& energy \& water & 118 & $71 \%$ & 84 & 144 & $64 \%$ & 92 \\
\hline 17 & Transport & 217 & $78 \%$ & 169 & 322 & $81 \%$ & 261 \\
\hline 18 & Economic activities & 83 & $21 \%$ & 17 & 146 & $32 \%$ & 47 \\
\hline 19 & Other expenditures & 90 & $0 \%$ & 0 & 152 & $0 \%$ & 0 \\
\hline $1-19$ & $\begin{array}{l}\text { total "primary" } \\
\text { expenditures }\end{array}$ & 2.936 & $75 \%{ }^{2}$ & 2.191 & 4.825 & $78 \%{ }^{2}$ & 3.759 \\
\hline 20 & $\begin{array}{l}\text { unconditional transfers } \\
\text { to other levels of } \\
\text { government }\end{array}$ & 465 & - & - & -10 & - & - \\
\hline 21 & $\begin{array}{l}\text { Pensions for retired } \\
\text { public servants }\end{array}$ & 368 & - & - & 441 & - & - \\
\hline 22 & Interest payments & 338 & - & - & 416 & - & - \\
\hline $20-22$ & $\begin{array}{l}\text { total "fixed" } \\
\text { expenditures } \\
\end{array}$ & 1,170 & - & - & 846 & - & - \\
\hline $1-22$ & total expenditures & 4.107 & - & - & 5.671 & - & - \\
\hline
\end{tabular}

${ }^{1}$ In the function "Social Welfare" the bulk of per capita spending differences across states is due to different ratios of social welfare recipients in relation to the total population. Therefore we set this ratio equal to $90 \%$,

${ }^{2}$ Calculated by dividing total minimum per capita expenditures by total average expenditures. 
In table 5 we present our results. In the lower part of the table we report three types of expenditures that are excluded from our analysis: interest payments (row 22), spending for retired public servants (row 21) and spending on interjurisdictional unconditional transfers to the local government sector (20). These three expenditure components roughly coincide with our fixed cost parameter $a_{i}$ in our theoretical model. In the upper part of the table we report spending in 19 functions which we take into account in deriving an estimate of minimum standards. Column (1a) indicates average per capita spending across the eight West German area states and column (1b) presents the corresponding figure for the aggregate state and local government sector. Column (2a) reports the lowest per capita spending in the West German states in percent of the average per capita spending. Column (3a) shows the lowest per capita spending in the West German states. ${ }^{34}$ The columns (2b) and (3b) report the corresponding figures for the aggregate state and local government sector.

In the function tax collection, public order and safety (esp. police), schools as well as social welfare, virtually uniform per capita spending are observed and minimum per capita expenditures are $90 \%$ and above of average per capita spending. Only a few and rather unimportant functions yield estimates of minimum expenditures of less than $50 \%$ of average spending. In the line reporting the total of functions 1 - 19 we get an estimate of the average minimum primary spending ratio of about $75 \%$ at the state level and of about $78 \%$ at the aggregate of the state and local government sector. These estimates correspond to the ratio $\bar{g} / \mathrm{g}_{\mathrm{i}}$ in our theoretical model. Because fiscally weak states have lower average per capita spending as fiscally strong states, this ratio is higher in fiscally weak as in fiscally strong states. Thus minimum standard spending is of quite significant importance in Germany and in other countries too.

As a matter of course, we are well aware of the fact that our estimates reported in table 5 are rather rough and we would need a careful econometric investigation that takes control variables in each spending function into account. However, this is far beyond the scope of the present paper. Nevertheless, we believe that the data in table 5 provides us at least with a "feeling" of the relative importance of per capita minimum spending and the average estimates derived across all functions should not be that dramatically different from results that might be derived by using much more sophisticated approaches. As a matter of course, high minimum spending might well reflect governance problems in Germany. However, these problems are not swept away by introducing taxing autonomy at the state level and thus a careful modeling should take these restriction serious if the analysis seeks to derive credible policy conclusions.

\footnotetext{
${ }^{34}$ That means column (3a) is derived by multiplying the entries in column (1a) and (2a).
} 
In the empirical section we presented evidence on the distributional effects of introducing taxing autonomy at the state level assuming a cut in the federal income tax bill and a compensation of the foregone state tax revenues by introducing a state surtax on the federal income tax. We showed that the distributional impact of this policy is quite significant and results in rather large distributional effects at the expense of fiscally weak states. However, these calculations disregarded all potential counter effects that might be induced in the long-run by mechanisms at work under a regime of tax autonomy. In the theoretical part of the paper we argued that one should assume that the impact of tax competition between states is of rather limited quantitative importance. This property should hold at least in the short- and medium-run. Even if there would be counterbalancing effects of tax competition in the long-run, the question arises if politics would be able to handle the transition process which would take a rather long period of times, perhaps even several decades. We also showed that in Germany fiscally poorer states carry a significantly higher per capita fixed costs. In addition we presented a rather simple and rough estimate of the importance of spending on minimum standards. Our results suggest that on the average more than $70 \%$ of state spending - net of fixed cost - might be absorbed by meeting minimum standards. These results suggest, that minimum standards are of quite significant importance and should be incorporated in theoretical models.

\section{Conclusions}

Using a quite simple theoretical model we examined the question how fiscally weak and fiscally strong subnational governments - taking the institutional setting of the German states as a laboratory might respond to the introduction of taxing autonomy. In our model differences in the taxing capacity of states as well as differences in fixed costs have been taken into account and in addition, we incorporated minimum standards for the provision of public services. The theoretical model did not yield clear-cut answers to the question whether fiscally strong or fiscally weak states will collect higher surtaxes on federal income taxes. However, both fixed costs and especially minimum standards result in a significant bias towards the forecast, that fiscally weaker states will have to set higher surtaxes. The empirical part presented evidence on the quantitative importance of fixed cost as well as spending on minimum standards. In addition, we derived evidence on the distributional impact of the introduction of taxing autonomy for German states taking the effects on the fiscal equalization system into account.

We have to admit that the paper has some shortcomings that should be addressed in future research. In the theoretical part of the paper we simply assumed the effects that tax competition might have on the 
interregional distribution of the population as well as the average income away. This we justified by arguing that empirical research indicates that differences in taxation does not induce that much interregional migration of households within nations. Households are severely hampered in migration by the availability of jobs, the closeness to friends and families as well as social and cultural ties. As a matter of course, one should expect that in the long-run the relative importance of these factors lose importance and thus our analysis should be looked upon as investigating the short- and medium-run. The estimate derived on the importance of spending on minimum standards in the empirical also needs further refinement.

Our results on the effects of introducing taxing autonomy at the state level are rather critical with respect to the effects of such a switch in regime in Germany. Taking our arguments and evidence seriously would mean that there is a high probability that fiscal disparities increase in Germany across states because fiscally weak states - especially the East German states having a fiscal capacity of less than $50 \%$ of the West German average - might be negatively affected by distributional effects resulting out of differences in surtaxes and the fiscal equalization system. In addition, because the German Constitution asks policy makers at the state and national level to strive "for equal living conditions", politics as well as the public opinion in Germany is rather sensitive to distributional effects. Economists have to take this factor into account if they want to be taken seriously as policy advisors!

As a matter of course, despite the critical results, introducing taxing autonomy at the state level and letting tax competition work is by no means a no-policy-option in Germany. However, politics would have to introduce some quite significant changes. The most important change would be a change in mind with respect to the political focus on regional distribution in Germany. This might make it even necessary to change the Constitution and get rid of the Constitutional command for striving for equal living conditions. However, at least currently such steps can hardly be imagined. It would be hard for policy makers in Germany to explain to the public that politics at the EU level fight for tax harmonization and tax policy coordination and at the same time introduce taxation heterogeneity at home. In addition, introducing taxing autonomy at the state level in Germany should go hand in hand with the introduction of tough debt restrictions at the state level in Germany, such as in most of the Swiss Cantons or U.S. states. Currently, especially fiscally weak states use debt financing intensively and state government debt in Germany exploded in the last 15 years. Without stiff debt restrictions policy makers would be tempted to issue new public debt instead of using the tax instrument to finance additional public services. 


\section{Literature}

Baretti, C. u. a. (2000), Chancen und Grenzen des föderalen Wettbewerbs, ifo Beiträge zur Wirtschaftsforschung, München.

Baretti, C., B. Huber and K. Lichtblau (2002), A Tax on Tax Revenue: The Incentive Effects of Equalizing Transfers: Evidence from Germany, International Tax and Public Finance, 9 (2002), 631-649.

Bertelsmann-Stiftung (2008), Bürger und Föderalismus: Eine Umfrage zur Rolle der Bundesländer, Gütersloh 2008.

Büttner, T. and R. Schwager (2003), Länderautonomie in der Einkommensteuer: Konsequenzen eines Zuschlagsmodells, Jahrbücher für Nationalökonomie und Statistik, 223/5, 532-555.

Feld, L. P. (2000), Tax Competition and Income Redistribution: An Empirical Analysis for Switzerland, Public Choice, 105, 125-164.

Feld, L. P., and B. Frey (2000), Die Auswirkungen des kantonalen Wettbewerbs auf den Kanton Zürich: Möglichkeiten einer rationalen Steuerreform, Gutachten für das kantonale Steueramt des Kantons Zürich, Zürich 2000.

Feld, L. P. and G. Kirchgässner (2001), Income Tax Competition at the State and Local Level in Switzerland, Regional Science and Urban Economics, 31, 181-213.

Fuest, C. (2008), Steuerwettbewerb unter den Bundesländern: Wären die finanzschwachen Länder die Verlierer?, in: K. Konrad and B. Jochimsen (eds.): Föderalismusreform II: Neuordnung von Autonomie und Verantwortung, 119-134, Peter Lang Verlag, Berlin.

Hoyt, W. (1992), Market Power of Large Cities and Policy Differences in Metropolitan Areas, Regional Science and Urban Economic, 22, 539-558.

Jourmard, J. and P. M. Kongsrud (2003), Fiscal relations across government level, OECD Economic Studies, 36, 155-229.

Keen, M. (1998), Vertical Tax Externalities in the Theory of Fiscal Federalism, IMF Staff Papers, 45(3).

Keen, M. und C. Kotsogiannis (2002), Does Federalism Lead to Excessively High Taxes?, in: American Economic Review, Vol. 92, No. 1, pp. 363-370.

Kirchgässner, G. and W.W. Pommerehne (1996), Tax Harmonization and Tax Competition in the European Union: Lessons from Switzerland, Journal of Public Economics, 60, 351-371.

Liebig, T. and A. Sousa-Poza (2006), The Influence of Taxes on Migration: Evidence from Switzerland, Cambridge Journal of Economics, 30, 235-252.

Liebig, T., P. Puhani and A. Sousa-Poza (2007), Taxation and Interregional Migration - Evidence from the Swiss Census using Community-Level Variation in Income Tax Rates, Journal of Regional Science, 47, 807-836.

Musgrave, R. (1961), Approaches to Fiscal Theory of Fiscal Federalism, in: NBER (ed.), Public Finances: Needs, Sources and Utilization: A Conference of the Universities - National Bureau Committee for Economic Research, Princeton University Press, Princeton, 97-134..

OECD (1998), Harmful Tax Competition - An emerging global issue, OECD, Paris, 1998.

Prud'homme, Rémy (1995), The Dangers of Decentralization, The World Bank Research Observer, 10 (2), 201-220.

Seitz, H. (2008a), Föderalismusreform zwischen Anspruch und Wirklichkeit, in: K. Konrad and B. Jochimsen (eds.): Föderalismusreform II: Neuordnung von Autonomie und Verantwortung, 135-156, Peter Lang Verlag, Berlin.

Seitz, H. (2008b), Die Bundesbestimmtheit der Länderausgaben, Wirtschaftsdienst, 5/2008, 340-348.

Tullock, G. (1969), Federalism: Problems of Scale, Public Choice, 4, 19-29.

Wildasin, D. (1991), Some Rudimentary Duopolity Theory, Regional Science and Urban Economics, $21,393-421$.

Zodrow, G. and P. Mieszkowski (1986): Pigou, Tiebout, Property Taxation and the Underprovision of Local Public Goods, Journal of Urban Economics, 1986, 356-370. 


\section{CESifo Working Paper Series}

for full list see www.cesifo-group.org/wp

(address: Poschingerstr. 5, 81679 Munich, Germany, office@cesifo.de)

2277 Bas Jacobs, Is Prescott Right? Welfare State Policies and the Incentives to Work, Learn and Retire, April 2008

2278 Burkhard Heer and Alfred Maußner, Value Function Iteration as a Solution Method for the Ramsey Model, April 2008

2279 Jarko Fidrmuc and Christa Hainz, Integrating with their Feet: Cross-Border Lending at the German-Austrian Border, April 2008

2280 Kristof Dascher and Alexander Haupt, The Political Economy of Regional Integration Projects at Borders where Rich and Poor Meet: The Role of Cross-Border Shopping and Community Sorting, April 2008

2281 Katrin Assenmacher-Wesche and M. Hashem Pesaran, A VECX* Model of the Swiss Economy, April 2008

2282 Christophe Rault, Robert Sova and Ana Maria Sova, Modeling International Trade Flows between CEEC and OECD Countries, April 2008

2283 Timo Boppart, Josef Falkinger, Volker Grossmann, Ulrich Woitek and Gabriela Wüthrich, Qualifying Religion: The Role of Plural Identities for Educational Production, April 2008

2284 Armin Falk, David Huffman and W. Bentley MacLeod, Institutions and Contract Enforcement, April 2008

2285 Axel Dreher and Stefan Voigt, Does Membership in International Organizations Increase Governments' Credibility? Testing the Effects of Delegating Powers, April 2008

2286 Xavier Freixas and Bruno M. Parigi, Lender of Last Resort and Bank Closure Policy, April 2008

2287 Regina Dionisius, Samuel Muehlemann, Harald Pfeifer, Günter Walden, Felix Wenzelmann and Stefan C. Wolter, Cost and Benefit of Apprenticeship Training - A Comparison of Germany and Switzerland, April 2008

2288 Francesco Daveri and Cecilia Jona-Lasinio, Off-Shoring and Productivity Growth in the Italian Manufacturing Industries, April 2008

2289 Mikael Priks, Do Surveillance Cameras Affect Unruly Behavior? A Close Look at Grandstands, April 2008

2290 Marianna Belloc and Daniela Federici, A Two-Country NATREX Model for the Euro/Dollar, April 2008 
2291 Nicolas Treich, The Value of a Statistical Life under Ambiguity Aversion, April 2008

2292 J. Atsu Amegashie, Socially-Tolerable Discrimination, April 2008

2293 M. Hashem Pesaran and Andreas Pick, Forecasting Random Walks Under Drift Instability, April 2008

2294 Steven Brakman, Gus Garita, Harry Garretsen and Charles van Marrewijk, Unlocking the Value of Cross-Border Mergers and Acquisitions, May 2008

2295 Eric O’N. Fisher and Kathryn G. Marshall, The Structure of the American Economy, May 2008

2296 Claudia M. Buch and Martin Schlotter, Regional Origins of Employment Volatility: Evidence from German States, May 2008

2297 Helmuth Cremer, Philippe De Donder, Dario Maldonado and Pierre Pestieau, Taxing Sin Goods and Subsidizing Health Care, May 2008

2298 Reinhilde Veugelers and Frederick van der Ploeg, Reforming European Universities: Scope for an Evidence-Based Process, May 2008

2299 Jon H. Fiva and Lars J. Kirkebøen, Does the Housing Market React to New Information on School Quality?, May 2008

2300 Tina Klautke and Alfons J. Weichenrieder, Interest Income Tax Evasion, the EU Savings Directive, and Capital Market Effects, May 2008

2301 Harald Badinger and Peter Egger, GM Estimation of Higher Order Spatial Autoregressive Processes in Panel Data Error Component Models, May 2008

2302 Jan K. Brueckner, Slot-Based Approaches to Airport Congestion Management, May 2008

2303 Sören Blomquist, Vidar Christiansen and Luca Micheletto, Public Provision of Private Goods and Nondistortionary Marginal Tax Rates, May 2008

2304 Dan Anderberg and Alessandro Balestrino, The Political Economy of Post-Compulsory Education Policy with Endogenous Credit Constraints, May 2008

2305 Tomer Blumkin, Yoram Margalioth and Efraim Sadka, The Role of Stigma in the Design of Welfare Programs, May 2008

2306 Vesa Kanniainen and Paolo M. Panteghini, Tax Neutrality: Illusion or Reality? The Case of Entrepreneurship, May 2008

2307 Thomas Dohmen, Armin Falk, David Huffman and Uwe Sunde, The Intergenerational Transmission of Risk and Trust Attitudes, May 2008 
2308 Guglielmo Maria Caporale and Mario Cerrato, Using Chebyshev Polynomials to Approximate Partial Differential Equations, May 2008

2309 Peter Egger and Doina Maria Radulescu, Labour Taxation and Foreign Direct Investment, May 2008

2310 Laurent Linnemer, Dissipative Advertising Signals Quality even without Repeat Purchases, May 2008

2311 Jordi Jofre-Monseny and Albert Solé-Ollé, Which Communities should be afraid of Mobility? The Effects of Agglomeration Economies on the Sensitivity of Firm Location to Local Taxes, May 2008

2312 Andreas Haufler and Ferdinand Mittermaier, Unionisation Triggers Tax Incentives to Attract Foreign Direct Investment, May 2008

2313 Ronel Elul and Piero Gottardi, Bankruptcy: Is it enough to Forgive or must we also Forget?, May 2008

2314 Andreas Irmen and Johanna Kuehnel, Productive Government Expenditure and Economic Growth, May 2008

2315 Beate Henschel, Carsten Pohl and Marcel Thum, Demographic Change and Regional Labour Markets: The Case of Eastern Germany, May 2008

2316 Gabriel Felbermayr, Wido Geis and Wilhelm Kohler, Restrictive Immigration Policy in Germany: Pains and Gains Foregone?, May 2008

2317 Michael Hofmann, Gerhard Kempkes and Helmut Seitz, Demographic Change and Public Sector Budgets in a Federal System, May 2008

2318 Paul De Grauwe, Macroeconomic Modeling when Agents are Imperfectly Informed, June 2008

2319 Johann K. Brunner and Susanne Pech, Optimum Taxation of Inheritances, June 2008

2320 Thomas Eichner and Marco Runkel, Corporate Income Taxation of Multinationals in a General Equilibrium Model, June 2008

2321 Rainald Borck and Matthias Wrede, Subsidies for Intracity and Intercity Commuting, June 2008

2322 Patricia Apps and Ray Rees, Testing the Pareto Efficiency of Household Resource Allocations, June 2008

2323 Amihai Glazer, Vesa Kanniainen and Panu Poutvaara, Firms' Ethics, Consumer Boycotts, and Signalling, June 2008

2324 Claudia M. Buch, Jörg Döpke and Kerstin Stahn, Great Moderation at the Firm Level? Unconditional vs. Conditional Output Volatility, June 2008 
2325 Helmuth Cremer, Philippe De Donder, Dario Maldonado and Pierre Pestieau, Forced Saving, Redistribution and Nonlinear Social Security Schemes, June 2008

2326 M. Hashem Pesaran and Paolo Zaffaroni, Optimal Asset Allocation with Factor Models for Large Portfolios, June 2008

2327 Harald Badinger and Peter Egger, Horizontal versus Vertical Interdependence in Multinational Activity, June 2008

2328 Jan K. Brueckner and Harris Selod, A Theory of Urban Squatting and Land-Tenure Formalization in Developing Countries, June 2008

2329 Paolo M. Panteghini, Corporate Debt, Hybrid Securities and the Effective Tax Rate, June 2008

2330 Guglielmo Maria Caporale, Juncal Cuñado and Luis A. Gil-Alana, Modelling Long-Run Trends and Cycles in Financial Time Series Data, June 2008

2331 Avi Ben-Bassat and Momi Dahan, Social Identity and Voter Turnout, June 2008

2332 Martin R. West and Ludger Wößmann, "Every Catholic Child in a Catholic School”: Historical Resistance to State Schooling, Contemporary Private Competition, and Student Achievement across Countries, June 2008

2333 Erkki Koskela and Panu Poutvaara, Outsourcing and Labor Taxation in Dual Labor Markets, June 2008

2334 Philippe Choné and Laurent Linnemer, Optimal Litigation Strategies with Signaling and Screening, June 2008

2335 Albert Solé-Ollé and Pilar Sorribas-Navarro, Does Partisan Alignment Affect the Electoral Reward of Intergovernmental Transfers?, June 2008

2336 Antonio Cabrales and Piero Gottardi, Markets for Information: Of Inefficient Firewalls and Efficient Monopolies, June 2008

2337 Sumon Majumdar and Sharun W. Mukand, The Leader as Catalyst - on Leadership and the Mechanics of Institutional Change, June 2008

2338 Ulrich Hange, Tax Competition, Elastic Labor Supply, and Growth, June 2008

2339 Guy Laroque and Bernard Salanié, Does Fertility Respond to Financial Incentives?, June 2008

2340 Adriano Paggiaro, Enrico Rettore and Ugo Trivellato, The Effect of Extending the Duration of Eligibility in an Italian Labour Market Programme for Dismissed Workers, June 2008

2341 Helmut Seitz, Minimum Standards, Fixed Costs and Taxing Autonomy of Subnational Governments, June 2008 